\title{
Mitul personal în proza lui V. Voiculescu
}

\author{
Drd. CĂȘUNEANU-PANAITIU Aura-Valentina \\ Universitatea „Dunărea de Jos” din Galați
}

\begin{abstract}
The psychocritical reading proposed by theorist Ch. Mauron entails that the depths of the associative network of a literary work actuate the imaginative matrix of the author's personal myth, a "phantasm" evolving through time, coordinating memories, literary materials, objects and readings, without being able to separate itself from adolescence conflicts or from traumatic biographical events. Thus, images can be explained and interpreted by comparing the biographical context to the evolution of the myth. In Charles Mauron's view, psychocriticism is founded on texts overlapping, with a view to highlight the network of associations, and also on the analysis of the writer's obsessions, of his various themes and dreams, followed by the identification of the personal myth and by the interpretation of the outcomes obtained by studying the literary works in comparison with elements from the writer's life.
\end{abstract}

Keywords: psychocriticism, phantasm, personal myth, network of associations

Situați într-o zonă de clivaj al culturilor și civilizațiilor, între Orient și Occident, între efortul de recuperare și tendința de globalizare, în lumea posibilului, accentul se mută de pe funcționalitatea spațiului pe aceea a timpului cosmic. Cultura noastră este una de tip tragic fiind determinată de relația dintre cosmo și antropocentrism, iar ființa umană este asimilată de cosmosul integrator și e problematizată apoi din unghiul antroposului. Pe fundalul unei culturi arhaice, medievale, moderne, profilul identitar al eului empiric se conturează în funcție de identitatea sa psihosocială, de contextul în care trăiește, de grupurile la care aderă, de conduita sa morală în raport cu factorul social, cultural, politic. Criteriul politic a făcut posibilă clasificarea Literaturilor române postbelice, după Ion Simuț, în patru categorii: oportunistă, evazionistă, literatură subversivă, disidentă și literatura exilului. Perioada cuprinsă între anii 1945-1960 este una ostilă afirmării marilor talente întrucât criteriul politic este cel în funcție de care se decide soarta literaturii române. Incepând cu anii 1945-1946, pentru autorul V. Voiculescu începe o lungă călătorie în sine, care va echivala cu o renaștere spirituală și începe să scrie proză cu toate că au existat unele încercări de texte cu caracter confesiv, memorialistic în perioada în care viziunea lui era una sămănătoristă. Refuzând orice colaborare cu regimul totalitar, el scrie, pentru a se exprima pe sine, sieși, o literatură evazionistă [Ion Simuț, 2017:350] care nu 
respectă rigorile impuse și al cărei formalism estetic l-a făcut să supraviețuiască, opera sa postbelică, scrisă la 62 de ani, fiind publicată și recuperată postum. Plasat în context istoric, textul narativ devine spațiul jocului identitate-alteritate, în care multiple fațete ale identității sunt revelate de perspectivele de lectură. Având ca suport câteva texte în proză ale lui autorului V. Voiculescu ne propunem să realizăm o analiză psihocritică. Suprapunere textelor unui autor duce la apariția imaginilor obsedante, a rețelei de asociații care persistă și care face posibilă manifestarea eului profund, scriptural din conștiința scriitorului, devoalând gândurile latente, fantasmagoriile, amintirile eului biografic. Vom descoperi o rețea de asociații, grupuri de imagini și vom urmări dacă se repetă și dacă sunt produse de fantezia imaginativă, care duce la descoperirea mitului personal, care este expresia personalității inconștiente a scriitorului V. Voiculescu.

Narațiunile sale de mică întindere sunt editate în două volume Povestiri, 1966 și se situează pe trepte valorice diferite, unele rămânând simple anecdote (Probe, Cap de zimbru, Fata din Java), altele fiind adevărate capodopere (Lostrița, Căprioara din vis, Behaviorism, Schimnicul, Pescarul Amin) [Dumitru Micu în Scurtă istorie a literaturii române, vol II].

Suprapunerea textelor în proză dezvăluie o lumea arhaică, primitivă, magică, fabuloasă care tulbură prin intruziune, prin camuflarea sacrului, a fantasticului în profan, lumea contemporană. Tema comună a povestirilor lui Voiculescu este permanenta înfruntare între civilizaţia prezentă, raţională, tehnicizată, şi lumea veche a miturilor, a legendelor o lume autentică, generatoare de viață, așa putând fi explicată preferința autorului de a recupera un spațiu primordial, autentic.

În povestirile propuse analizei psihocritice, autorul folosește ca tehnică narativă povestirea în ramă, ceea ce presupune ca prin procedeul inserției, într-o narațiune să fie introdusă o a doua, în care unul dintre personaje preia rolul de narator povestind o întâmplare la care a participat ca protagonist.

Scrisă în urmă cu 71 de ani, povestirea În mijlocul lupilor debutează cu povestea inițială "rama", în care descrie întâlnirea unui grup de vânători în jurul unei discuții despre fauna cinegetică din țara noastră. Relieful țării încă mai oferă prilejul ca omul să vâneze în condiții arhaice, ca la începutul lumii când între vânat și vânător exista o relație sacră. Vânătoarea devine artă, Magie, știință, încordarea energiilor, ritual magic atunci când prada (leul, mamutul, ursul) este mai puternică decât el. Astfel de scene apar zugrăvite în peșterile preistorice autorul arătând o preocupare aparte față de destinul oamenilor paleoliticului, de cavernele cu oase de urși. Magistratul preia rolul de narator și- 
și amintește o experiență din tinerețe, introducând fantasticul povestirii sale în „realitatea povestitorului. Repartizat, în tinerețe, într-un sat în care totul respira arhaicitate, judecătorul se referă la un spațiu arhaic scos parcă de sub trecerea timpului, un loc neatins de civilizație: pădurile "feciorelnice", meleagurile par a fi "încremenite în vechime", atmosfera este de "arhaism și primitivitate tulburătoare", totul pare desprins dintr-o eră demult încheiată în restul lumii[V.Voiculescu,2000:291].

Preocupat de a avansa în carieră, personajul-narator adună material pentru un studiu de drept popular și despre obiceiurile pământului. Intriga povestirii se produce în momentul în care judecătorul trebuie să rezolve un caz, și îl achită pe Lupar pentru că nu acesta a ucis o căprioară, ci doar a găsit-o după ce au sfâșiato lupii. Auzind tot felul de povești în legătură cu el, judecătorul vrea să-1 cunoască. Află că trăiește în condiții primitive, izolat de oameni, că se îmbracă în haine de animale, și din cauza mirosului pe care îl emană în jurul său, câinii îl latră și oamenii îl ocolesc. Nu e vrăjitor, dar înțelege graiul lupilor pentru că trăiește în mijlocul fiarelor. Asupra portretului său fizic primitiv și a celui moral există puncte de vedere diferite, sătenii îl percep ca pe un sălbatic, lipsit de sentimente, un vrăjitor, iar magistratul îl vede ca pe un personaj tragic care trăiește izolat într-o lume care nu-l acceptă. Impresionat de dialogul Luparului cu lupii din noaptea magică a Sf. Andrei, când este posibilă comunicarea cu lumea de dincolo, naratorul cade în mijlocul celor cinci lupi, "așezaţi în cerc, stând în șezut ca la sfat, pe picioarele dindărăt" momentul din care nu-și mai amintește, apoi, nimic, nici cum a ajuns acasă. Dacă nu ar fi fost rănit la gleznă ar fi crezut că totul a fost doar un vis. Ca în toate celelalte texte, finalul este deschis, întâmplările rămânând în zona fantasticului.

În Căprioara din vis, Bătrânul sculptor definește visul ca „protomemorie" [Mircea Braga,2008:287] ,ț̂așnind din straturile adânci ale ființei noastre, ne destăinuiesc stări demult trăite, trecute în fondul nostru, care izbucnesc în vis cum într-un cutremur năpădesc prin crăpăturile scoarței vinele apelor fierbinți din miezul pământului"'[V. Voiculescu, 2000:70]. Visele simbolizează o trăire personală și dezvăluirea unei experiențe obștești, a unei întâmplări colective. Simbolistica lor este complexă, tainică, numai cel hărăzit are un vis profetic și importante sunt „cele care ne întorc înapoi, la viețile din străvechime"'[V. Voiculescu, 2000:70]. Și aici, formula narativă este povestirea în ramă și prin procedeul inserției se trece dintr-un plan în altul; bătrânul sculptor povestește o întâmplare la care a fost protagonist în urmă cu 23 de ani. Împătimit de vânătoare atunci, recunoscut, face expediții, iar priveliștile și scenele trăite prind formă în lada cu pământ pe care o poartă întotdeauna cu el. 
De Crăciun, la castelul prințului B.., se îndrăgostește de domnița Irina, nepoata gazdei uitând de artă și de vânătoare. Ea reprezintă arhetipul frumuseții, imaginea chipului ei fiind asociată cu cea a Dianei, zeița cerească și cu a unei căprioare ce alerga fiind înconjurată de haitele de câini de vânătoare. Într- o seară, înainte de plecare, plăsmuiește într-un bloc de zăpadă silueta domniței Irina, în tunică scurtă, brațele goale, cu o tolbă cu săgeți în spate. Prin intermediul visului se ipostaziază în Bătrânul sculptor-pruncul sugar, tânărul vânător, artistul- având revelația propriei identități, redescoperindu-se în diferite chipuri. Disoluția eului, metamorfoza sunt semnele alterității. Tânărul artist, vânătorul a lăsat prada pentru umbra ei săpată pe un os, ceea ce în plan spiritual înseamnă că printr-o putere magică exercitată asupra lui 1-a convertit să privească lumea cu frumusețe, cu dragoste, cu iubire. Gestul său din final când nu toarnă bustul în bronz și nu-l cioplește în marmură ci îl lasă în lut este semnificativ și poate fi interpretat ca o obsesie a autorului de a se contopi cu materia din care este plăsmuit, într-o fuziune cu elementul lumii primitive.

Motivul dublului prin care se concentrează dorințele refulate ale eului conștient inspirate de timpul legendar, de societatea modernă, de lumea satului, a vânătorii este reprezentat de personajul modern camuflat în lumea arhaică, așezat față în față cu cel primitiv. Povestirile dezvăluie întâmplări neobișnuite, fantastice care s-au născut din străfundurile istoriei și ale legendei și au pătruns în viața modernă. Suprapunerea face să apară o ,tramă epică”[Ov.S. Crohmălniceanu, 1984:136], iar repetiția ei obsesivă are un caracter involuntar. În aproape toate textele menționate, remarcăm motivul vânătorii fie ca pretext al întâlnirii personajelor surprinse întotdeauna în actiune, fie ca secvență epică din care întâmplările miraculoase nu lipsesc, natura spațiului arhaic pe care îl imaginează autorul fiind misterioasă, cu întâmplări ce nu pot fi explicate rațional. Povestirile ilustrează o dublă realitate, una exterioară, rațională, corespunzând omului modern şi conştientului, iar alta interioară, magică, specifică omului arhaic şi subconştientului." [Adriana Nicula, 2011: 38]

Având ca reper realizarea unității spirituale a lumii, „resuscitarea mentalității arhetipale în lumea contemporană" [Dinu Pillat ] se dezvoltă o rețea de imagini definită la nivelul scriiturii, concretizată în simboluri: vânătoare primitivă, incantații, vrăji, guri de peșteri pline de osemintele trecutului, Lume primitivă, grotă, văpaie, idoli de lut, piei sălbatice.

Metamorfoza om-animal este o fantasmă posibilă în imaginarul autorului pe fundalul coliziunii dintre lumea arhaică și cea modernă. Astfel, arhetipul animalului totemic, strămoș al oamenilor de pe aceste meleaguri, apare 
în diverse ipostaze, de la pește ca simbol al lumii apelor, până la lup și urs, simboluri ambivalente ale puterii reprezentând binele și răul.

Persistența acestei imagini a mentalității arhaice în aceste texte, dovedește că ea obsedează imaginația autorului și constituie o fantasmă. Femeia=arta=vânătoarea mijlocesc întoarcerea la origini, „pe tărâmurile negre ale uitării, în inconștientul atoateștiutor, pentru a se întâlni cu sine însuși, cu omul primitiv, care a avut întâiul fior de artă urmărind o căprioară ce-i amintea de o fată"[V. Voiculescu, 2000:76]. Obsesia primitivismului este revelată de antropomorfizarea imaginii în care Junon, câinele Irinei „,s-a aplecat cu duioșie și i-a dat să sugă, aiurind poate sunt unul din puii ei" refăcând scena zugrăvită în peșterile preistorice despre care aflăm în În mijlocul lupilor, când toți răsfoiesc albumele cu reproduceri care înfățișează scene de vânătoare primitivă. Urmărind încărcătura afectivă care însoțește această fantasmă constatăm că ea provoacă o stare de spaimă. Vânătoarea cea mare se produce în zile de sărbătoare: de Bobotează, „,când se deschid cerurile și joacă toate comorile pământului"[V. Voiculescu, 2000:73], de Sf Andrei, sărbătoarea precreștină cu triplă semnificație magică: ziua lupilor, când este posibilă comunicarea cu lumea de dincolo, noaptea strigoilor, când sunt alungate duhurile necurate sau invocarea ursitului.

Mitemele specifice gândirii arhaice definesc viziunea originală a autorului care evocă existența cotidiană sub aura fantastică a vremurilor străvechi, preistorice, cu credințe totemice, încărcate de tâlc. Spațiul arhaic, pădurile "feciorelnice", meleagurile ce par a fi "încremenite în vechime", atmosfera de "arhaism și primitivitate tulburătoare", sunt reprezentative pentru relevarea conexiunii dintre micro și macrocosmos, legătura dintre regnuri, lumea arhaică fiind complexă. Omul se află în situația limită de a se sustrage prin intermediul visului din tensiunea generată de invazia elementelor lumii moderne într-un spațiu pe care îl coordonează. Lumea modernă descoperă în oglinda timpului lumea arhetipală, omul arhaic care coexistă cu simbolul mitic până la identificarea cu animalele, reproducându-le purtarea, obiceiurile (totemul: lupul, ursul).

Autorul este solidar spiritului popular, recunoscând cu entuziasm că cel mai mare noroc din viața sa este că s-a născut la țară, trăind o viață ,,autentic rurală, ritmată de datini și străvechi obiceiuri". În subcapitolul Tradiţionalismul ca fatalitate a substratului, Claudia Ileana Spineanu susține că Opera lui V. Voiculescu se naște dintr-o viziune panteistă asupra naturii în care omul trăiește pe deplin ordinea acesteia, se supune ritmurilor ei, o idealizează, iar când o pierde, se zbate dramatic să o regăsească. $\mathrm{O}$ altă rețea de imagini pornește de la 
tema Cunoașterii reprezentată în mod simbolic de laitmotivul ochiului, lutului, în timp ce bătrânul semnifică imaginea dublului în inconștientul autorului. Personajul tipic pe care-l propune este un însingurat, izolat de istorie și de oameni. Fatalitatea destinului său se circumscrie obsesiei recuperatoare a timpului pierdut. Protagoniștii sunt indivizi care trăiesc la periferia societății, în intimitate cu stihiile naturii și care au tendința de a se dubla, bivalența existențială fiind sugerată de motivul chipului de lut și omul-animal. Luparul a reușit să se ridice deasupra lupilor, să devină un fel de arhetip al lupului, marele lup spiritual, o ipostază cosmică a cărei văpaie pe care o împrăștie în jurul său este magie. Nimfa cu ochii verzi, părul de bronz aurit sunt miteme care obsedează universul imaginar al autorului prin care se zbate să refacă spațiul edenic, desacralizându-l prin coborârea în cotidianul existențial.

Comportamentul personajelor se explică nu numai prin prismă freudiană, psihanalitică ci și psihocritică. Omul își satisface dorințele inconștiente pe cale imaginară, prin activitatea spiritului numită, fantezie, iar observațiile unei lecturi psihocritice sunt raportate la persoana scriitorului, la încercarea lui de a recupera imaginea care îl urmărește obsesiv și care este o figură masculină: cea a bătrânului mag.

In Fata din Java, aparent, scenariul rămâne același, însă circumstanțele se schimbă. Mediul citadin prezentat este spațiul Bucureștilor, cu asfaltul încins în care apar la un loc urme fosile cu labe primitive, și în care tânărul vulcan aflat în plină erupție literară se retrage în subsolul asudat, unde lucrează la cel de-al doilea volum de poezii, după ce primul, Stele negre a fost un succes. Cele două personaje naratorul și unchiul său, Mihail, reprezintă două concepții opuse: cel dintâi este visătorul, iar celălalt raționalul, pragmaticul. Cel din urmă încearcă să-1 facă să renunțe la litere, pe primul, și să urmeze Politehnica pentru a deveni inginer și pentru a-1 angaja la una dintre firmele lui din Java unde face comerț cu zahăr, piper și scorțișoară. Pentru a-1 convinge, îi povestește cum și-a făcut iluzii despre o fată javaneză care în final s-a dovedit a fi un un sul din ierburi uscate care te desparte de tine însuți în timpul somnului. Obsedat de fata javaneză, tânărul se visează cu volumul de poezii alungit ca un sul fie „,îmbrăcat în piele galbenă, fie preschimbată într-o luxuriantă femeie".

Aceeași obsesie a imaginii satului primitiv- descris ca loc sălbatic, sărăcie de preistorie, cu locuințe împrejmuite $\mathrm{cu}$ ziduri de piatră ceea ce sugerează siguranța spațiului ocrotitor, apare și în Iubire magică. O consecință a migrării, a ruperii este evoluția care are loc în afara așezării, în satul vechi omul rămânând arhaic, nu se supune Timpului, ci iese din Timp: „ei nu datorează vieții nimic altceva decât existența. N-au fatalitate. Au numai ursită. Nu vin 
încărcați de nicio moștenire"'[V.Voiculescu,175]. Aflat în mijlocul unei lumi arhaice în care puricii sunt înlăturați din încăpere, de un vrăjitor, printr-un descântec, făcându-i să se lipească de lama cuțitului, lucios ca argintul pe care se reflectă lumina soarelui, încearcă, prin puterea magică a minții să o recompună pe Margareta din Faust de Goethe ca pe eternul feminin care potențează în cer pasiunile care pentru noi sunt păcate ce ne strivesc. La fel, personajul mânat de elanul faustic al totalității, se află sfâșiat între două puteri de vrajă: „,cea malefică, aducătoare de iubire și cea benefică, eliberatoare de viziuni eschatologice" [V.Voiculescu, 2000: 13].

Prima ipostază a Mărgăritei potențează vitalitatea personajului narator: „M-a plesnit fără veste atâta erotism, atâta răscol sexual necunoscut mie până atunci"'[189]. Vraja îi dezvăluie personajului o altă Mărgărită, aproape decăzută din condiția biologicului, vraja nu înseamnă o ,,contrafacere, o măsluire a realității, ci restituirea celei de-a doua componente a naturalului, restituire care nu poate avea loc decât la nivel psihologic, pentru care simultaneitatea contrariilor este o realitate de drept și de fapt"[Mircea Braga, 2008:300]. În ipostaza îndrăgostitului, personajul narator face un pact cu vrăjitoarea, căreia îi vinde sufletul numai ca Mărgărita să-l iubească. Astfel se produce o degradare și o „prăbușire a organicului" "[Mircea Braga, 2008:302] și „o desublimare a animei angelice" a femeii cum ar fi spus Corin Braga: „în fața mea sta o strigoaică, cu ochi de albuș de ou răscopt, plesnit de dogoare...pe crăcanele oaselor picioarelor, măruntaiele spurcate clocoteu ca niște șerpi veninoși. Și duhoarea morții umplu deodată lumea"[V. Voiculescu, 2000:190]

Suprapunând aceste texte datate 1947 peste unul scris în 1909, la distanţă de 38 de ani, Astăzi împlinesc douăzeci și cinci de ani, vom descoperi persistența imaginii „bătrânului, groaznic, gol, descărnat care aleargă în goana calului peste câmpuri. Barba îi înfășoară pieptul și-și amestecă firele cu coama calului, pletele-i flutură pe spate și în pornirea-i furtunoasă pare purtat de un uragan" [V.Voiculescu, 2000:681]. Dedesuptul rețelei de imagini se manifestă aceeași obsesie a întoarcerii și a coborârii în sine. Cuplurile și mentalitățile opuse figurează un eu scindat asupra căruia exercită presiuni puternice, contrare, partea lui ideală și cea inconștientă. Coborând în zonele adânci ale inconștientului, investigând legăturile dintre cuvinte se desprind metaforele obsedante care pun în lumină mitul personal al autorului. Timpul, perceput în dimensiunea sa cosmică, izolarea/ singurătatea sunt forme de manifestare ale suferinței; încărcătura afectivă este complexă și reflectă fațete diferite ale eului. Una dintre ele este cea construită pe obsesia imagoului parental care se suprapune pe imaginea primitivă a omului; această fantasmă poate revela o 
situație tensionată, o teamă față de tatăl despre care autorul nu vorbește în mărturisirile sale. Este posibil ca pe fondul acestei relații tensionate susținute de secvențele în care personajul se teme de a nu fi văzut, ori de a nu sângera pentru că vraja s-ar stinge, bănuim noi, că ea dezvoltă o suferință, o teamă și în același timp o încercare de a triumfa, de a poseda și de a se impune ca figură autoritară în fața celor cinci copii cum Luparul hiperbolizat îi domină pe cei cinci lupi.

O altă rețea de imagini dezvăluie obsesia imagoul psihologic prin sustragerea autorului din teroarea istoriei. Defazarea eului se produce pe fundalul unei traume ce ascunde sentimentul culpabilității că ființa, chir și atunci când iubește poate provoca suferință, pasiunile fiind păcatele care ne stivesc sub ele. Rețeaua de imagini, din jurul mitemelor osul, glezna, măruntaiele spurcate face referire la structura materială, corporală a ființei umane supusă unui proces de degradare și dezagregare, proces susținut și prin punerea în funcțiune a simţului olfactiv. Ele sunt simboluri Thanatice prin care se dezvăluie anxietatea autorului, teama de necunoscut. Mitul personal al scriitorului V. Voiculescu este cel al cunoașterii prin suferință, în timp ce mitul literar propriu-zis ar putea fi Iubire magică, văpaia din degetele și din ochii lui era un fel de materie fosforescentă ca la licurici, o magie după cum este descris personajul narator, Luparul.

Dihotomia verde-auriu-lumină, decorurile, huma, stânca, peștera, grota, pasiunea personajului de a scrie un Studiu în folclor și nu despre folclor, dezvăluie poziția lui de a nu explica actul magic ci de a-l lăsa pe lector în umbra visului său. Prin actul scriiturii, autorul preferă călătoria spirituală, în spațiul primordial al omului preistoric care a învățat și a reușit prin practici magice să supraviețuiască /între fiarele sălbatice, care pot defini metaforic teroarea istoriei, actorii regimului totalitar, întrucât textele puse în discuție vor fi publicate postum. Este perioada când, după moartea soției (1946) autorul nu mai publică nimic, dar scrie cel mai mult tocmai pentru a încerca să reconstituie, ca într-un puzzle, imaginea unitară a sufletului său. 


\section{Bibliografie}

Bădărău, George, Proza lui Vasile Voiculescu - modalităţi de realizare a fantasticului, Editura Princeps Edit, Iaşi, 2006

Braga, Mircea, V. Voiculescu in orizontul tradiționalismului, Editura Minerva, Bucureşti, 1984

Braga, Mircea, V. Voiculescu Măștile căutării de sine (o hermaneutică a orizonturilor creației), Editura Academiei Române, București, 2008

Dumitru, Anastasia, Ipostaze ale fantasticului în proza lui Vasile Voiculescu, Editura Universitară, București, 2011

Micu, Dumitru, Scurtă istorie a literaturii române, vol II, Editura Iriana, 1995

Nicula, Adriana, Tipuri de povestire la Mihail Sadoveanu şi Vasile Voiculescu, Editura Print ATU, Sibiu, 2011

Pascu, Eugenia, Vasile Voiculescu-poet și prozator, Editura Timpul, Reșița, 2002

Podosu, Ion, Universul prozei lui Vasile Voiculescu, Editura Limes, Cluj-Napoca, 2007

Voiculescu, Vasile, Opera literară. Proza, Ediție îngrijită, prefață cronologie de Roxana Sorescu, Editura Cartex 2000, Bucureşti, 2003 